\title{
Is Road Pricing a Sustainable Policy? Jakarta Case
}

\author{
Muhammad Nanang Prayudyanto ${ }^{1, *}$ and Ofyar Z. Tamin ${ }^{2}$ \\ ${ }^{1}$ Lecturer of Civil Engineering, University of Ibn Khaldun (UIKA), Bogor \\ ${ }^{2}$ Post Graduate School of Department of Civil Engineering, Institute of Technology \\ Bandung (ITB), Bandung
}

\begin{abstract}
Urban road pricing involves direct charging of drivers for the use of the road network, usually during peak periods. The main objectives for the introduction of a road pricing scheme, in a congested city network, include reduction of delays, environmental improvement and revenue increase. These objectives are closely associated with the concepts of sustainable mobility in urban areas with respect to social equity, economic efficiency, and environmental responsibility. There have been intensive discussions about sustainable transportation in Indonesia. In tune with the issue of climate change and the decline in the ability to provide fuel, this paper is intended to look at the perspective of road pricing from the standpoint of traffic flow, travel speed, emissions reduction, and energy consumption as well as pricing scheme. As pricing will be imposed for the Moslem community, it should conform with Islamic tax income which is for the benefits of poor, needy and less privileged people in the society. The conclusion drawn is that the frenzied application of road pricing will be able to improve traffic in Greater Jakarta but the sustainability of pricing should be adjusted with Islamic tax income.
\end{abstract}

Keywords: sustainable transport, road pricing, public transport, Islamic tax.

\section{Introduction}

In a congested environment, each additional trip causes all other similar trips to be delayed. This delay to other users has a cost which is referred to as the "external" cost and is much greater than the cost of the trip to individual users. The economic theory underlying road pricing is to bring these costs into consideration and, as a result, allocates road space more efficiently. Those prepared to pay to obtain a higher quality of service, and the absence of those not prepared to pay benefits to all remaining road users including public transport passengers.

ERP will divert car and taxi trips to public transport, producing a small percentage increase in overall demand for public transport. Complementary measures such as providing park

\footnotetext{
*Corresponding author: muhammadprayudyanto@gmail.com
} 
and ride facilities, improving public transport interchanges, providing feeder services and improving public transport information system should be considered.

The subject of the ERP plan has been discussed since the early 2000s as one of the transportation policies for controlling the CBD's congestion levels. In recent years, the ERP plan has developed in a concrete way, as the central government passed Government Regulation (PP) No. 32/2011 for Traffic Management and Engineering, which provides a legal framework within which Jakarta's local government may execute the ERP plan [26].

\subsection{Public Acceptance}

Implementation of ERP will not be possible without a general public consensus on the objectives and principles of the proposal. A well-planned and executed public consultation programme to demonstrate how ERP works and to allow public input into the development of system objectives can promote awareness of the ERP system as a measure to relieve traffic congestion and develop understanding in the community for its possible introduction. The public should be consulted specifically on the acceptable traffic condition in terms of traffic speeds, size of the charging zone, the charging level, the type of vehicles which may be charged and the use of the ERP revenue.

\section{Literature Study}

\subsection{Experience from Road Pricing Implementation}

Hong Kong ERP is feasible and agreed due to traffic condition that average road traffic speeds have fallen by $11 \%$ in 10 years and air quality has worsened, which is partly attributable to congestion. The added benefit in Hong Kong is that most public transport does not require subsidy, as the network of bus and mini-bus services operates commercially, all with integrated smartcard ticketing, so growth in demand is met by operators investing themselves. Even the metro system pays for itself, and there has been an ongoing investment to expand it, supported by revenue from the property development at station sites [23].

Hong Kong first conducted a pilot test on the electronic road pricing system between 1983 and 1985 with positive results, but when it tried to implement an actual electronic road pricing, it failed because of public opposition [10].

\subsection{Role of Pricing in Moslem Society}

The idea of the tax has been in existence since when money was not used as a medium of transaction for many decades to provide administrative support to the government. The tax system is adopted by governments to raise funds for the financing of public expenditure. The current governments employ tax revenues for the payment of defense, to construct roads, buildings as well as operating schools, hospitals, to offer the poor food and medical care to the people [3].

In Islamic concept, there is a moral obligation to pay Zakat for the government to function and support the poor. Hence, failure to pay Zakat by a Muslim is considered as unethical behavior. In the case where the government engaged in an act that is immoral according to Islam, evading of tax cannot be unethical to Muslims [11]. Islamic taxes are based on the Islamic Sharia or law; that establishes guiding principles for implementations. In these case, Islamic taxes or financial products significantly differ from the conventional 
taxes or financial product. Islamic taxes are based on the Islamic law sanctions that on both the taxable land legal status and religious status or public taxpayers [3]. The Islamic system of economy is a particular construct that members of the Islamic faith follow. For instance, the Islamic laws on taxes paid particular attention to interest and emphasis on the wealth tax that is considered to be from aggregate savings. The Islamic scripture has shown that government has every justification to force individuals to raise tax if Zakat is not enough to cover the allowable cost of government by Sharia [11].

\section{Feasibility for Jakarta ERP Implementation}

To tackle congestion in Jakarta, since 1992 has begun steps to limit the number of passengers of private vehicles on the main corridor, with a "3 in 1" which means the minimum number of passengers in the vehicle were 3 people. This step was also intended to demonstrate to the world when the ongoing summit of non-aligned countries, that Jakarta was not as severe as expected so that the meeting can be arranged with more timely. Early results of 3 months after the policy was imposed showed a decrease of 24 percent in the number of private cars entering the zone and dramatic increases (over 150 percent) in the average travel speed by private cars.

Road Pricing as one of the Travel Demand Management strategies has been reformulated due to the high traffic growth rebound after the national economic crisis during 1998-2000 [5]. A study by Bappenas-JICA [4] recommended this issue. The City Administration proposed to replace the 3-in-1 policy with an area pricing scheme (or a "sticker" scheme) to take place in a similar area. The scheme sounds much like the Singapore Area Licensing Scheme. Cars will need to buy and display stickers to enter the area in peak hours $(7.30-9.30$ am and $5.00-7.00 \mathrm{pm})$.

\subsection{Pro-Cons}

Ethics is an important theme for Muslims as primary sources of word view on Islam, from the Holy Quran as well as the Sunnah of the Prophet Muhammad (peace be upon him). Allah has stated in the Holy Quran that; "The noblest of you insight of Allāh is the best of you in conduct" (Al Hujurat:13) [1]. And the Prophet Muhammad (PBUH) stated that in the Hadith; "I have been sent for the purpose of perfecting good morals." (Ibn Hanbal, No: 8595) [2]. Pricing should be treated to improve social welfare and the system should be guided following the Holy Quran and Hadith.

Opposition politicians and a major consumer's organization have come out against the scheme. They said, among other things, that the system would discriminate against the poor. On the other hand, Jakarta's Governor argued that the scheme would hurt only the rich who are the ones who drive cars. But the opposition leader also argued that public transport was insufficient, said that more buses should be put onto the road before the scheme is implemented. However, in the popular mind at least, the scheme has not been considered a success. Traffic growth between 1992 and 1997 was very high so much of the benefit was probably overwhelmed by the increasing traffic. In addition, a practice emerged of youths offering to ride as passengers for a small fee ("jockeys") to allow drivers to meet the occupancy requirement. This also undermined the image of the scheme (although it demonstrated some willingness to pay on parts of the drivers).

The policy of traffic restraint in Jakarta was enacted in the Structure Plan since 1985 and then be revised in the Art. 6/99 [6]. The area of restraint divided Jakarta into 4 categories, as shown in Figure 1. In 2004, the National Planning Bureau (Bappenas) 
supported by JICA recommended the development restraint area to accommodate the pressure of activity in the southern part of the city (Fig.1, left).

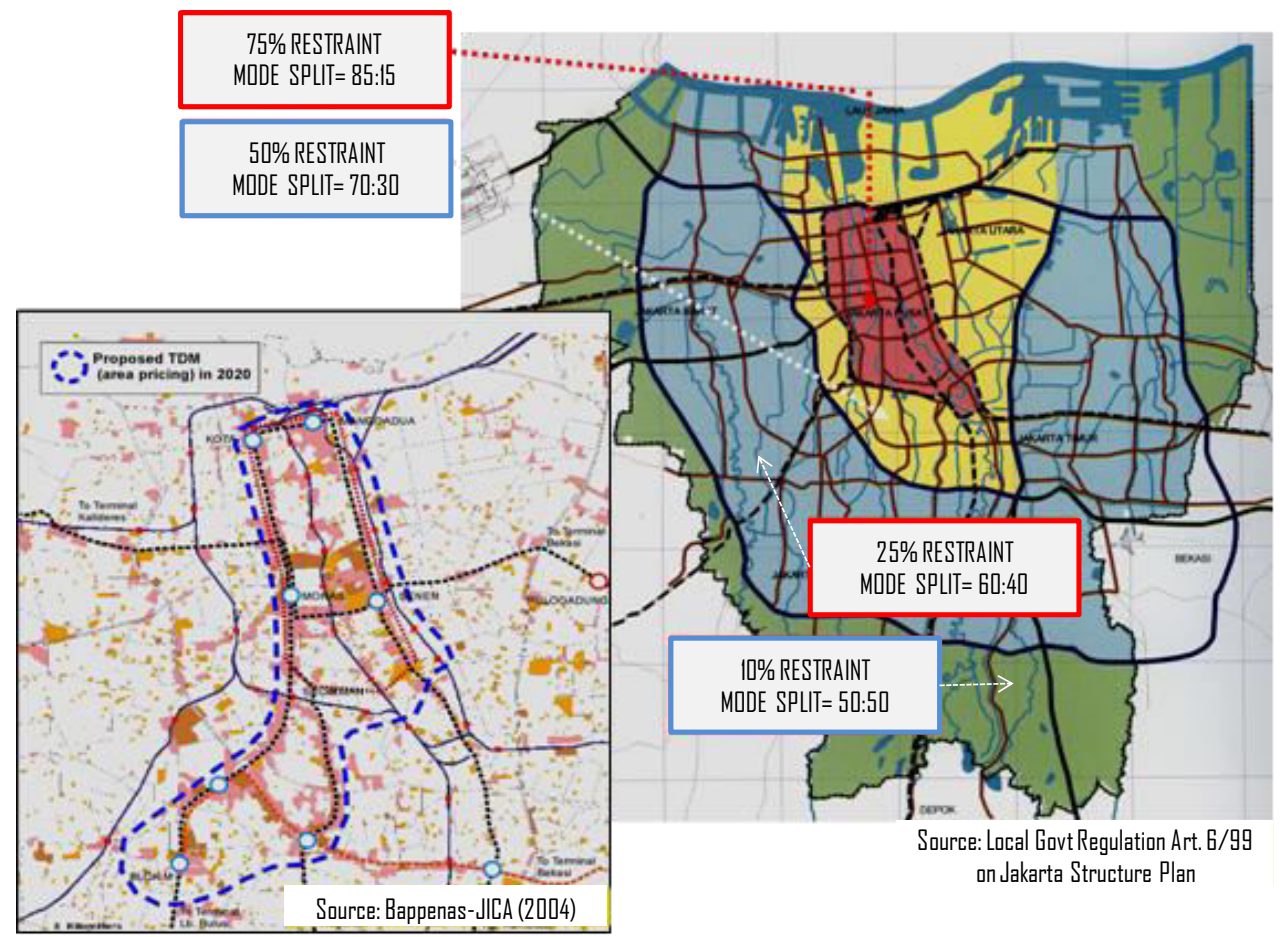

Fig. 1. Government policy for traffic restraint in Jakarta

\subsection{Technical Assessment}

The model comprising Daily Activity Pattern, Time of Day, Mode-Distribution and SubWork based Tour [16]. Nested Logit and Multinomial Logit Model are used to analyze the O-D on mode, time and level of income. Small and Ibanez [15] determined the seven basic forms of congestion pricing. Some approaches that have been developed to include congestion effects in route choice models and equilibrium assignment seem to be the preferred technique on practical and theoretical grounds. This type of assignment technique is consistent with Wardrop's equilibrium principle which can be expressed in terms of the mathematical program.

- Objective Function:

$$
Z(x)=\sum_{x_{a}} \int_{0}^{x_{a}} t_{a}(x) d x
$$

- Subject to

$$
\begin{array}{ll}
x_{a} \geq 0, t_{a} \geq 0 & \forall a \\
x_{a}=\sum_{r, a, k} f_{r}^{k} \delta_{r, s}^{a, k} & \forall a, k, r, s \\
f_{r, s}^{k}, q_{r s} \geq 0 & \forall k, r, s
\end{array}
$$


Where:

$\boldsymbol{Z}(\boldsymbol{x}) \quad$ : objective function to be optimized, as total travel time in the entire road network as a function of vehicle flow, $\mathrm{x}$ on each link (hour)

$\boldsymbol{t}_{\boldsymbol{a}}\left(\boldsymbol{x}_{\boldsymbol{a}}\right)$ : travel time on a link an as a function of vehicle flow on link $a$ (hour)

$\boldsymbol{x}_{\boldsymbol{a}} \quad$ : vehicle flow on link $a$ (vehicle/hour)

$\boldsymbol{f}_{r, s}^{\boldsymbol{k}} \quad$ : vehicle flow on path $k$ connecting origin $r$ and destination $s$ (vehicle/hour)

$\boldsymbol{q}_{r s} \quad$ : total vehicle flow connecting origin $r$ and destination $s$ (vehicle/hour)

$\boldsymbol{\delta}_{\boldsymbol{r}, \boldsymbol{s}}^{\boldsymbol{a}, \boldsymbol{k}} \mathrm{k} \quad$ : coincidence matrix denoting vehicle flow on link $a$ of path $k$ connecting origin $r$ and destination $s$ (not unit)

Prayudyanto [12,13], Yudhistira [17], and Fergusson [8,9] divided the effects of TDM strategies in the surrounding region (site), the corridor and the wider area (regional). Each is shown with the target to be achieved and changes in parameters that would occur (Table $1)$.

Table 1. TDM evaluation objectives

\begin{tabular}{|l|l|l|l|l|l|l|}
\hline $\begin{array}{l}\text { PERFORMANCE } \\
\text { MEASURES }\end{array}$ & CHANGES & TARGET & DATA & METHOD & MODEL \\
\hline CORRIDOR & Reduce & $\Delta \#$ vehicle trips & DO, RP & $\begin{array}{l}\text { Vehicle } \\
\text { Count }\end{array}$ & $\begin{array}{l}\text { Trip } \\
\text { Generation }\end{array}$ \\
\hline Vehicle Trips & Constant & $\Delta \#$ person trips & DO, RP & $\begin{array}{l}\text { Vehicle } \\
\text { Count }\end{array}$ & $\begin{array}{l}\text { Trip } \\
\text { Generation }\end{array}$ \\
\hline Person Trips & Reduce & $\Delta \#$ VMT & RP & Survey & $\begin{array}{l}\text { Trip } \\
\text { Distribution }\end{array}$ \\
\hline $\begin{array}{l}\text { Vehicle Miles } \\
\text { of Travel }\end{array}$ & Reduce & $\Delta \#$ VHT & DO, RP & Survey & $\begin{array}{l}\text { Route } \\
\text { Assignment }\end{array}$ \\
\hline $\begin{array}{l}\text { Vehicle Hours } \\
\text { of Travel }\end{array}$ & Increase & $\begin{array}{l}\Delta \text { level of } \\
\text { service }\end{array}$ & DO & Model & Network \\
\hline $\begin{array}{l}\text { Level of Service } \\
\text { Traffic Delay }\end{array}$ & Reduce & $\begin{array}{l}\Delta \text { hours of } \\
\text { delay }\end{array}$ & DO & Model & Network \\
\hline REGIONAL & Reduce & $\begin{array}{l}\Delta \text { gallons of } \\
\text { gasoline }\end{array}$ & Model & Model & Projection \\
\hline Fuel Consumption \\
\hline $\begin{array}{l}\Delta \text { pollutions of } \\
\text { Car Emission }\end{array}$ & Reduce & Model & Model & Emission \\
\hline
\end{tabular}

Source: Ferguson [8,9]

Remarks:

$\mathrm{SOV}=$ single occupant vehicle

$\mathrm{VMT}=$ vehicle miles of travel

$\mathrm{PMT}=$ person miles of travel

VHT $=$ vehicle hours of travel
$\mathrm{P} / \mathrm{V}=$ persons per vehicle

$\mathrm{DO}=$ direct observation

$\mathrm{RP}=$ revealed preference

$\mathrm{SP}=$ stated preference 
Prayudyanto [13] provides a set of analysis of the alternative selection process:

- 44 alternatives including single, dual and triple combinations alternative strategies are made for the so-called "long-list".

- The selected alternative scenarios are chosen from the list to become the so-called "short list", using BRT as the basic scenario and parking and road pricing as the other mainstream strategies. This then called "dual strategies".

- The analysis was carried out on the single and dual strategy. The single strategy, with each set of a stand-alone alternative on the basis of the same road network and public transport network. The alternative was taken from T3 (three times the unit pricing road pricing, IDR 16,500), and P2 (additional parking fee of IDR 2,000).

- Dual strategy, by setting a combination of strategies, by selecting a combination a combined strategy. The strategy chosen was a combination of:

- T1P2 (the unit price is a one-time road pricing (IDR 5,500) and additional parking fee of IDR 2,000).

- T3P2 (three times the unit price of road pricing (IDR 16,500) and an additional parking fee of IDR 2,000).

- T5P2 (five times the unit price of road pricing (IDR 27,500) and an additional parking fee of IDR 2,000).

- T3P4 (three times the unit price of road pricing (IDR 16,500) and an additional parking fee of IDR 4,000).

The network performance shows the significant improvement using Road Pricing and BRT scenario. The benefit rises both in the TDM area and outside TDM area as well, as shown in Table 2.

Table 2. The performance with and without TDM

\begin{tabular}{|c|c|c|c|c|}
\hline Scenario & Area & Veh-Km & Veh-Hr & Speed (km/h) \\
\hline \multirow{2}{*}{ Do Nothing 2020 } & Greater Jakarta & $11,494,152$ & $8,590,830$ & 27.70 \\
\cline { 2 - 5 } & TDM Area & 258,368 & 17,771 & 44.06 \\
\hline \multirow{2}{*}{$\begin{array}{c}\text { TDM + } \\
\text { BRT2020 }\end{array}$} & Greater Jakarta & $10,525,409$ & $6,789,561$ & 29.07 \\
\cline { 2 - 5 } & TDM Area & 165,010 & 5,576 & 47.12 \\
\hline \multirow{2}{*}{ Impact } & Greater Jakarta & 968,743 & $1,801,269$ & 1 \\
\cline { 2 - 5 } & TDM Area & 93,358 & 12,195 & 3 \\
\cline { 2 - 5 } & Greater Jakarta & $8.43 \%$ & $20.97 \%$ & $4.95 \%$ \\
\cline { 2 - 5 } & TDM Area & $36.13 \%$ & $68.62 \%$ & $6.95 \%$ \\
\hline
\end{tabular}

Table 2 shows that the benefit at Greater Jakarta can be measured by the reduction of vehicle-kms at $8.43 \%$, and subsequently $20.97 \%$ vehicle-hours reduction and $4.95 \%$ of speed increment. In the TDM area the benefit of reduction in vehicles-km is $36.13 \%$, and $68.62 \%$ for vehicles-hours reduction and $6.95 \%$ for speed increment respectively. 
Having implemented the Road Pricing scenario, the impact of traffic volume and speed in the restraint area and its surroundings were explored. The benefit of the road pricing scenario is obvious as reflected by reducing the amount of traffic volume in the restraint area and increasing its travel speed, as shown in Figure 2.
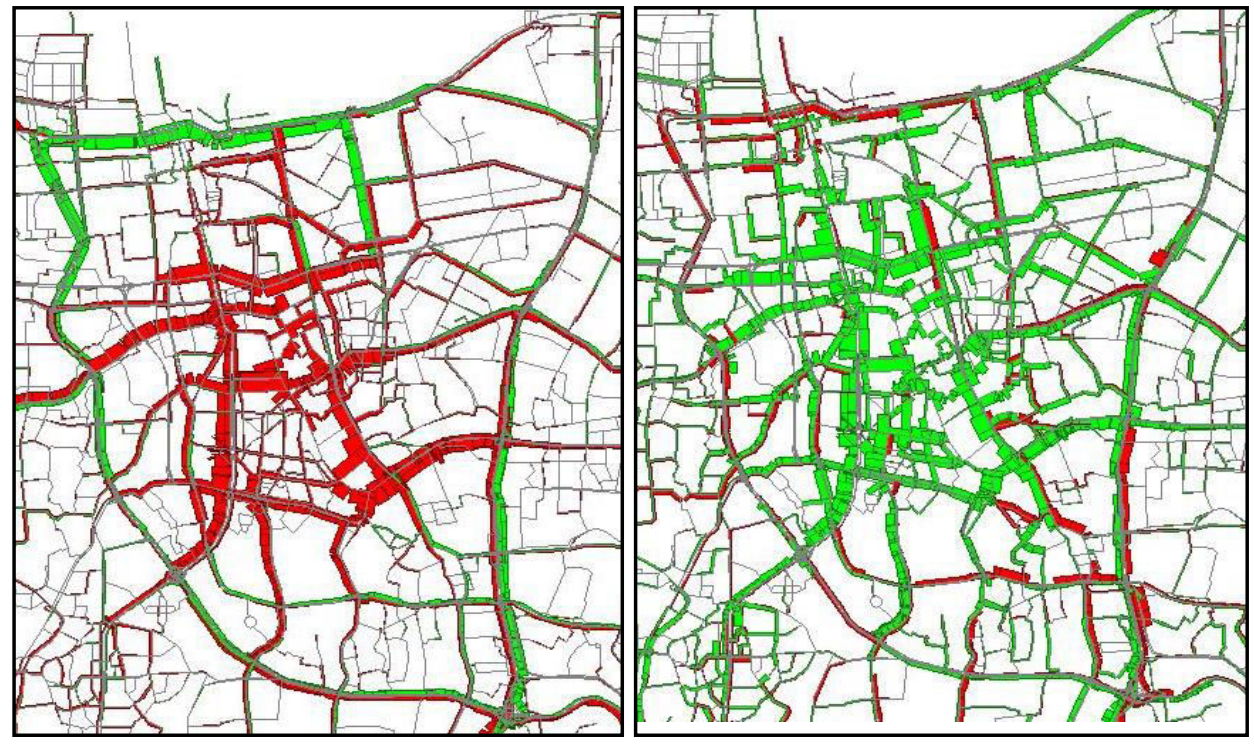

Fig. 2. Impacts on volume (left) and speed (right)

Note: Red (left picture) means volume reduces, Green (right picture) means speed increases

The scenario 3 assumes the condition whereby all private vehicles entering the TDM area is charged by IDR 27,500, whereas, within the area, the parking rates are subject to additional cost of IDR 4,000. The analysis is done in the region 0 (Greater Jakarta), 1 (TDM region), 2 (TDM Area- Inner Tollway) and 3 (Inner Limit-JORR). Results of the analysis are presented in Table 3.

Table 3. TDM performances of scenario 3

\begin{tabular}{|l|r|r|r|}
\hline \multicolumn{1}{|c|}{ Region } & \multicolumn{1}{|c|}{ Vehicle-km } & \multicolumn{1}{c|}{ Vehicle-hours } & \multicolumn{1}{c|}{$\begin{array}{c}\text { Average Speed } \\
\mathbf{( K m} / \mathbf{h})\end{array}$} \\
\hline Greater Jakarta & $5,820,981$ & $4,821,359$ & 7.22 \\
\hline TDM & 114,282 & 3,463 & 38.50 \\
\hline TDM Area- Inner Tollway & $1,536,339$ & 280,384 & 34.10 \\
\hline Inner Limit-JORR & $2,971,318$ & $1,599,458$ & 1.25 \\
\hline
\end{tabular}


A review on the performance of transportation - based on the traffic performance, environmental impact and financing viability, which are combined using weighing factor for Jakarta [4] - is calculated and finally presented as scenario 3 (T3P2) resulting in the highest rank as in Figure 3.

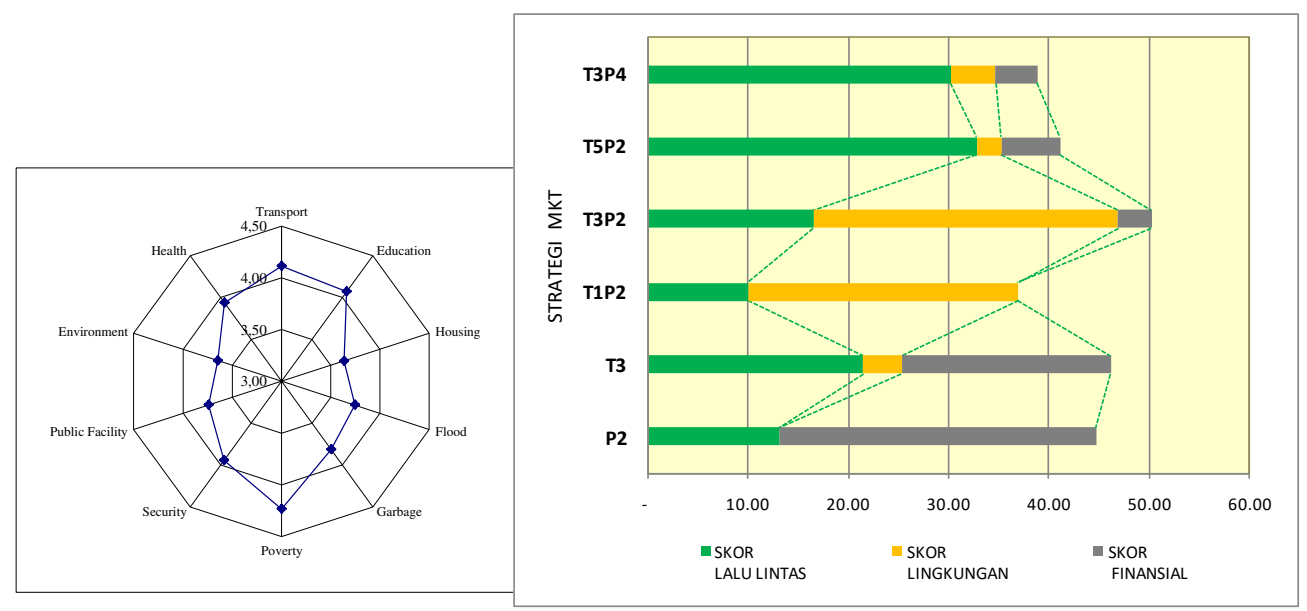

Fig. 3. Weighing Factor and Combined Evaluation

\subsection{Road Pricing Acceptance}

Road pricing acceptance is strongly accepted by political and social perception. Cracknell in Ensor [7] states the political acceptability should be considered in the road pricing implementation.

Pricing as a tax system in a religious country such as Indonesia would better if public acceptance is reached. The Pew Research Center survey of Muslims in 39 countries asked Muslims whether they want sharia law, a legal code based on the Quran and other Islamic scripture, to be the official law of the land in their country [14]. Responses on this question vary widely. Nearly all Muslims in Afghanistan (99\%) and most in Iraq (91\%) and Pakistan (84\%) support sharia law as official law. But in some other countries, especially in Eastern Europe and Central Asia - including Turkey (12\%), Kazakhstan (10\%) and Azerbaijan $(8 \%)$ - relatively few favor the implementation of sharia law. $72 \%$ of Indonesian Moslem favors making Islamic law for the country [14].

\section{Discussions}

There many factors that the study will not be implemented and ERP in Jakarta will be unsuccessful as reasoning below.

a) Public opinion poses another major challenge. Many drivers argue that road pricing as a double taxation to resist RPs. This challenge is also reflected in the socalled "free rider problem" for any un-priced service; users are not willing to pay for a service that has been traditionally free. Therefore, to promote successful road pricing schemes, researchers, policymakers, and public officials should offer a clear vision for the public. Otherwise, RP schemes would constantly face public resistance. 
b) The road pricing schemes that are only profitable might not be sustainable since they might significantly increase travel costs and diminish transport system performance. Likewise, pricing systems that only manage congestion can become unsustainable because they can be very costly to society. However, to promote a sustainable path for road pricing systems, we should note that all the abovementioned aspects are connected and a social welfare analysis can address these connections.

c) Traffic volume is not elastic with tariffs. In Road Pricing concept, to manage congestion, prices are generally set to reduce peak-hour traffic demand. In this case, the tariff will not be unlimited unless social impact will be vulnerable. This unelastic tariff will be possible because although the rich people of Jakarta are few their interests (meeting, important agendas) are causing ERP location as a single alternative. As seen from the Jakarta toll road which remains stalled although tariff increases continue to be applied.

d) As set by government regulation, revenue from road pricing will be allocated for traffic management and public transport improvement.

e) Road pricing is a tax system that should adopt Islamic sharia in better alleviating the welfare.

\section{Conclusions}

The demand management system has been analyzed to be one of the important systems of both economic developments and for the servicing of government expenditure in both developing and developed economies including in Jakarta, Indonesia. Traffic will be better using traffic restraint implementation as indicated by improvement of travel speed and reduction of traffic volumes.

In the implementation of ERP for Jakarta, as the Moslem society more than $87 \%$, Islamic tax system should be considered, as it has been used in several countries.

Given that the economic conditions of the country have dwindled down as a result of economic crisis, it is recommended that the Jakarta Provincial government should start working on how best to handle Islamic tax collection. This is achievable once government provides real intention on how to assist the poor based on the Islamic requirements on the utilization of taxes. A visit to other countries that have using the system will provide a good insight on how to handle Islamic taxes.

\section{References}

1. The Holy Qur'an.

2. Hadith.

3. Aliyu, A.A., Alkali, M.Y., Alkali, I., "Islamic Perspective on the Impact of Ethics and Tax for Nigerian Economic Development", International Journal of Islamic Economics and Finance Studies, Vol: 2, Issue: 3, November (2016).

4. Bappenas-JICA., "The Study on Integrated Transportation Master Plan for Jabodetabek (Phase II)" Technical Report 2: Transportation and Demand Forecast, Jakarta (2004)

5. Barter, P., “Jakarta Area Pricing - Equitable or Not?", Sustran Discussion, Jakarta (1998)

6. DKI Jakarta Transportation Department, "Pattern of DKI Jakarta Macro Transportation", (2004) (in bahasa). 
7. Ensor, J.D. "Malaysia Transport Pricing Strategies, measures, and Policies Inception Report”. Malaysia Transport Research Group Massachusetts Institute of Technology February 22, (2004).

8. Ferguson, E., “Auckland Regional Travel Demand Management Strategy", New Zealand (2001)

9. Ferguson, E., "Travel Demand Management and Public Policy", Ashgate Publishing Ltd, Vermont (2000)

10. Hong Kong Government, Possible ERP System for Hong Kong, http://www.td.gov.hk/filemanager/en/content_524/erp_eng.pdf (2012)

11. Mcgee, R. W. The Ethics of Tax Evasion in Islam: A Comment. The Ethics of Tax Evasion in Theory and Practice, 3(1), 159-165. http://doi.org/10.1007/978-1-4614$\underline{1287-8}$ (2012).

12. Prayudyanto, M.N., and Tamin, O.Z., "Mode Shift Travel Demand Management Evaluation from Jakarta's Experience", Proceedings of the Eastern Asia Society for Transportation Studies (2009)

13. Prayudyanto, M.N., "Analysis of Optimization Strategies of Travel Demand Management Coping in Urban Transportation Problems (Case Jakarta Metropolitan City)", Post Graduate School, Institute of Technology Bandung (Unpublished, 2010)

14. Pew Research Center. Muslims and Islam: Key findings in the U.S. and around the world. http://www.pewresearch.org/fact-tank/2017/08/09/muslims-and-islam-keyfindings-in-the-u-s-and-around-the-world/ (2017).

15. Small, K., A, and Ibanez, J., G., "Road Pricing for Congestion Management: The Transition from Theory to Policy". In: Button, K.J., Verhoef, E.T. (eds.), "Road Pricing, Traffic Congestion and the Environment", Edward Elgar Publishing, Northampton (1998)

16. Yagi, S., "An Activity-Based Microsimulation Model of Travel Demand for Transportation Policy and Impact Analysis", Ph.D. Thesis, the University of Illinois at Chicago, USA, (2006)

17. Yudhistira, M.H. 2015 "On The Effects of The Electronic Road Pricing Plan in The Jakarta Metropolitan Area", A Dissertation of Doctor of Philosophy in Public Economics, National Graduate Institute of Policy Studies (2015). 